TE WHARE WĀNANGA O TE ŪPOKO O TE IKA A MĀUI

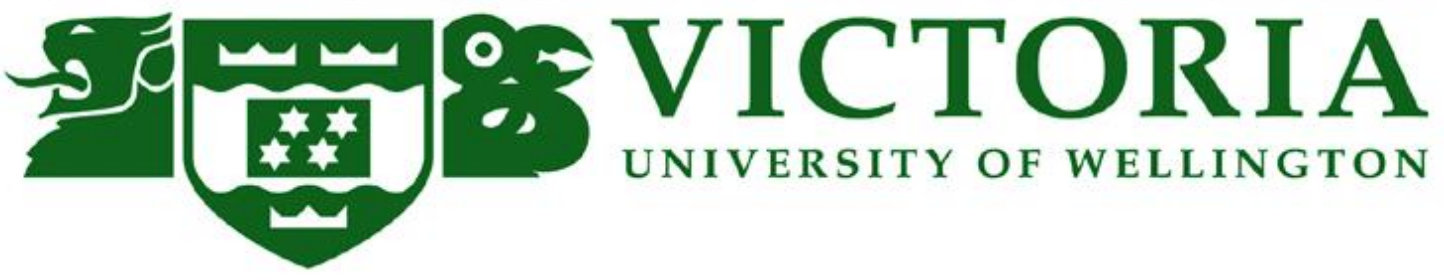

\title{
Impact of Information Culture and Information Behaviour on Information Quality
}

by

\section{Anna Sinitsyna}

\begin{abstract}
Submitted to the School of Information Management, Victoria Business School, Victoria University of Wellington in partial fulfilment of the requirements for the degree of Master of Information Management
\end{abstract}




\section{Contents}

Abstract.

Introduction. 3

Literature Review.

Formulating research questions and objectives...

Theoretical background of the research.

Information Quality

Information Quality characteristics/metrics.

Wang and Strong's conceptual framework for Information Quality.

Naumann and Rolker's IQ assessment framework.

Information Culture and Behaviour.

Oliver's Information Culture model.

Curry and Moore's exploratory model for assessing Information Culture.

Kettinger and Marchand's Information Orientation model.

Developing research model and hypothesis.

Methodology.

Developing measuring tools

Data collection.

Survey results analysis.

Discussion.

Conclusions.

References:

Appendix A. Survey Questionnaire.

Appendix B. Information Sheet for participants. 
Abstract.

Purpose: Although Information Quality (IQ) is a widely discussed topic, people's influence on the Information Quality remains insufficiently explored. There are many indicators in the academic literature that people play an important role in creating and maintaining information, however, there is a lack of studies investigating how people's behaviour and attitude towards information influence the Information Quality within the organisation. The purpose of this paper is to explore the impact of Information Culture and Information Behaviour dimensions on Information Quality.

Design/methodology/approach: An online survey has been conducted among office workers of Wellington based medium and large companies. Adapted from previous research questionnaires have been used to determine people's perceptions of the Information Culture of the companies, the Information Behaviour of employees and Information Quality.

Findings: Research reveals that Information Culture has moderate positive impact on Information Quality. Information Behaviour has a strong positive relationship with Information Quality.

Research limitations/implications: Research has drawn attention to Information Quality problems, but this time from a slightly different angle focusing on the impact of Information Culture and Information Behaviour on Information Quality. The presented study provides an insight into what factors of Information Culture and Information Behaviour are the most favourable for maintaining good quality information. This knowledge is important for organisations that seek ways of improving Information Quality. However, due to the limited time framework, the small sample and taking into account that this paper is probably the first research of its kind, the results need further investigation by other research studies.

Originality/value: The presented research appears to be the first of this kind and provides valuable knowledge into how employees might influence the quality of the information, which is the strategic resource of contemporary organisations. 


\section{Introduction.}

Information Quality is important for contemporary businesses because it impacts all aspects of organisational functioning. For example, according to Price Waterhouse Coopers and The Information Warehousing Institute, 88\% of all Information integration projects within US enterprises either fail or over-run their budgets due to poor Information Quality and $33 \%$ of organisations have delayed or cancelled implementation of new IT systems implementation because of poor information (Marsh, 2005).

Information Quality affects organisations of any size and nature in many ways. (Xu, Jeretta, Brown, \& Nord, 2002). Information Quality has an impact on all levels of the organisation: operational, tactical and strategic. Various organisational functions and outcomes depend on the level of Information Quality. Fulfilment of Enterprise-wide programmes such as Enterprise Resources Planning (Xu, Jeretta, Brown, \& Nord, 2002), Enterprise Risk Management (Ramchandra \& Sricant, 2006), and Customer Relationship Management (Henderson \& Murray, 2005), rely on Information Quality.

There is evidence that Information Quality is an important success factor for the implementation of Information Systems, Business Intelligence systems and Data Warehouse (Conradie \& Kruger, 2006; Ballou, \& Tayi, 1999). Information of good quality is the basis for decision making at all levels of the organisation. Maintaining Information quality at the appropriate level is important for everyone, whether a casual user of information resources or a decision-maker using corporate Information Systems to obtain information from different departments (Naumann \& Rolker, 2000).

Since Information Quality has been recognised as an important element that influences organisations, it is important to study which factors influence Information Quality so that Information Quality might be improved for its better use for organisational functioning and performance. There are many indicators in the academic literature that point to the fact that people's attitudes and behaviours towards information as well as information values and information management practices within the organisation influence Information Quality (Trembly, 2002; English, 2001). Most of the indicators mentioned above are scattered and dispersed within the academic sources and in most cases they are considered in conjunction with other, 
usually technical, factors such as Information System Quality and Software Quality. Employees' attitudes toward information and employees' actions toward information relate to the Information Behaviour concept. Information values and information management practices within the organisation relate to the Information Culture concept. Information Culture and Information Behaviour are considered as important organisational features that have an impact on the effective use of information and records management (Marchand, Kettinger, \& Rollins, 2011; Wright, 2013). However, there are no studies that investigate the impact of Information Culture and Information Behaviour on Information Quality.

At the same time, due to the development of Information and Communication Technologies people's role in the creation of information and consequently people's impact on Information Quality has increased over the past decades (Shankaranarayan, Ziad, \& Richard, 2003). So, the need to study how some aspects of employees' behaviours and organisation culture affect Information Quality has emerged.

The aim of this research is to investigate how Information Behaviours of employees and the Information Culture embedded into Organisational Culture influence Information Quality within an organisation. An important assumption of the research is that the terms "Data Quality" and "Information Quality" are used interchangeably as, in the context of typical enterprise, what has been applied for Data Quality can be applied for Information Quality. In addition, although the term "Data" is different from the term "Information" and is basically explained as processed "Data", for consistency, the term "Information" will be used through the research paper to refer both to "Data" and "Information".

The paper is organised as follows: the first section provides a Literature Review where the Information Quality issues are covered and a gap in the body of research is identified. The second section explains the theoretical background of the research topic. Then a model of the impact of Information Behaviour and Information Culture on Information Quality is provided and tested. The next sections are dedicated to the methodology of the research and Information collecting, testing of hypotheses, discussion of the results obtained, and implications, limitations and recommendations for future research. 


\section{Literature Review.}

There is a significant number of articles dedicated to different aspects of Information Quality and its possible effects within organisations in the academic literature (Ramchandra \& Sricant, 2006; Henderson \& Murray, 2005; Howles, 2014; English, 2008). In most cases, Information of good Quality is associated with a positive impact on a variety of organisational functions and processes and is suggested as a high priority area for businesses of any size and nature (Xu, Jeretta, Brown, \& Nord, 2002). Information Quality has been recognised as important by organisations from different industries and areas. It has been shown that Information Quality is essential for healthcare organisations (Brouwer \& Bindels, 2006), for financial and insurance companies (English, 2005), for manufacturing organisations (Gustavson \& Wanstrom, 2009), and so on.

Information Quality has a great influence on various organisational functions and outcomes, such as knowledge sharing behaviour (Durcikova \& Gray, 2009), mobile device adoption (Kim \& Han, 2011), trust in the IT artefact (Vance et al., 2008), user loyalty (Zhou et al., 2010), and customer satisfaction (Kekre et al., 1995) (as cited in Setia, Venkatesh, \& Joglekar, 2013, p. 567). Ramchandra and Sricant (2006) found that Information quality is a success factor for enterprise-wide programmes and, in particular, for Enterprise Risk Management. Moreover, Information Quality has a strong effect on implementing Enterprise Resource Planning systems (Xu, Jeretta, Brown, \& Nord, 2002), Customer Relationships Management (CRM) (Henderson \& Murray, 2005), Relationship Strategy Marketing and others (Khalil \& Harcar, 1999). Gorla, Somers and Wong (2010) have showed that Information Quality is positively associated with organisational impact.

Information Quality is one of the key determinants of the quality of a company's decisions and actions (Sharabati \& Hawajreh, 2012; Clikeman, 1999). Good Information Quality has been recognised as a basis for good decisions at all organisational levels. At an operational level, the quality of the information provided is important for customers' and employees' satisfaction; at the tactical level the quality of the information is crucial for decision making; at the strategic level companies require high quality information (e.g. information is relevant and complete) for defining and executing business 
strategies (Gorla, Somers, \& Wong, 2010). Since contemporary organisations rely heavily on Information Systems and Information Technologies when making their decisions, many of the research has been devoted to the exploring of Information Quality effects on implementation of broadly used technologies such as Data Warehouse (DW), Business Intelligence (BI)(Breur, 2009), and Big Data (BD) (Howles).

Conradie and Kruger (2006) believe that BI is effective if it allows management to make effective decisions. Decisions, in turn, are as good as the information they are based on. Modern technologies (Business Intelligence (BI), Data Warehouse, Big Data) allow companies to use the information in a most efficient way. However, decisions based on information derived from Data Warehouse are only as good as the Information quality of the Information warehouse (Yeo \& Rudra, 2000).

Information Quality has been found to be a crucial factor influencing Information Systems success (McLean \& Delone, 2003).

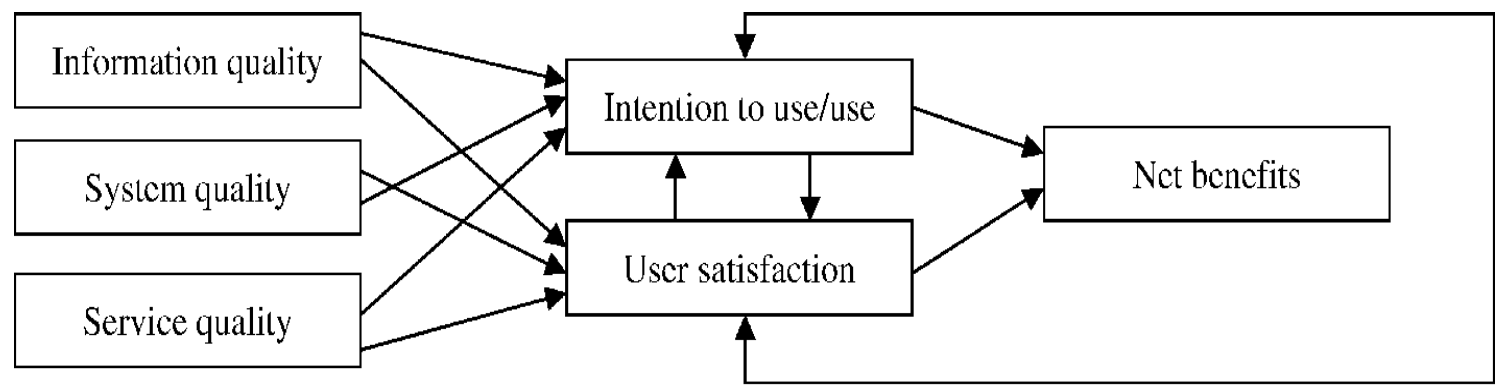

Source: DeLone and McLean (2003)

Picture 1. DeLone and McLean (2003) model.

According to the DeLone and McLean (2003) Information Systems success model, Information Quality influences Information System success.

Information Quality has such a strong effect on organisations that poor Information Quality can lead to multiple issues affecting different aspects of organisational functioning. Much attention has been paid to Information Quality related issues and to the negative impact that bad information has on organisations. There are several negative impacts that bad information has at the typical enterprise. On the operational level it causes lowered customer satisfaction, lowered employee satisfaction and increased cost. On the tactical level poor information will lead to poorer decision making, difficulties with implementing Information warehouse and other information systems, and even to increased organisational mistrust because once people have experience with incorrect or outdated information entered by other employees they 
will not trust their co-workers and information stored in the information systems. On the strategic level, poor Information will increase difficulties with creating and further executing of the organisational strategy, will contribute to the problem of information ownership and distract top management attention (Redman, 1998). Poor Information Quality can cost organisations millions of dollars (English, 1996; Pitney Bowes Business Insight, 2010). Firstly, the organisation will lose money directly due to processes failure; secondly, the organisation will have to pay to detect and correct errors and for the information rework (English, 1996). Fox, Guynes, Prybutok and Windsor (1999) explored in their paper the consequences of poor information and demonstrated that information of inadequate quality results in reduced revenues, overpayments, diminished goodwill, and weakened operational control. Poor information quality may seriously thwart the overall effectiveness of businesses (Mahanti, 2014).

There is strong evidence in the academic literature that Information Quality is important. It is shown that Information Quality influences the most vital organisational functions. Therefore, it is important to know what factors influence Information Quality. This knowledge will help organisations to improve Information Quality for further effective and efficient use of information for various organisational functions thus improving organisational performance.

Traditionally, Information Quality issues have been left to information technologies and to the technical professionals, whereas it has been shown that non-technical factors, in particular Information Management practices and employees' behaviour toward Information, have a great impact on Information Quality (English, 2008; Howles, 2014). The reasons for poor information quality have been widely investigated and discussed. Along with technical factors a number of non-technical reasons which cause bad information were identified. People and the way they treat information can be considered as non-technical factors, which influence Information Culture. The human factor play a very important role at each stage of information cycle, namely, collecting, cleaning, storing, using and maintaining (Howles, 2014). The quality of information will depend on who collects the information and how it is collected, who cleans the information, who is responsible for information reviewing and so on. Gonzales and Michael (2004) pointed out that the main reason for poor Information Quality is inadequate management. Fox, Guyness, Prybutok and Windsor (1999) have identified 
the following causes of errors in information: Information Systems and Information Technology itself and electronic transmission of Information, Information Systems management, and repetitive handling of Information by different individuals within the company, from Information collectors to top executives. The Data Warehousing Institute provides the statistics, which show that one of the main sources of Information Quality problems is Information entry by employees (Trembly, 2002). Minton and Young (2009) have argued that the major sources of Information quality issues are deliberate lies and misinterpretation by suppliers of information. Also, they pointed to other reasons for Information quality issues: translation, transformations and manipulations with Information, and information-entry and information acquisition errors. Ballou and Tayi (1999) have identified the reason for bad information as using the same information for multiple purposes, which can be quite different from its original purposes. In this case information that is perfectly suited for accomplishing somebody's working tasks might not work for another person with different objectives (Wand \& Wang, 1996). So, among the other factors that influence Information Quality people's behaviours toward information are of great importance. Information Technologies that are now available in the every office make people's impact on information and Information Quality even more significant.

Information Technologies provide a higher access to a larger amount of information and give employees possibilities freely change and create information within companies' information systems. This indicates the growing impact of employees on information and consequently on Information Quality. Welzer, Brumen, Golob, Sanchez, \& Druzovec (2005) have made an interesting point that the spread of electronic use of Information adds complexity to the IQ problems. Indeed, contemporary technologies have increased information volumes and further distributed information sources, while giving access to Information anywhere and anytime (Shankaranarayan, Ziad, \& Richard, 2003). IT has caused an explosion of information, because most technologies have simplified the process of access to information and helped to spread information (Sharabati \& Hawajreh, 2012). With increased reliance upon Information Technologies, individuals who used to be strictly the users of the information have now become Information entry clerks. However, "unlike information- entry professionals who are trained in the meaning of every field, many consumers are satisfied merely with 
accurate entering only of the Information that is needed to complete their tasks." (Pitney Bowes Business Insight, 2010). These factors stimulate the human role in creating information and the human impact on information quality.

As was discussed earlier, the development of new interactive web based technologies has given users more access to information and consequently more influence on information and Information Quality. As a result, Information Quality has become more dependent on people's behaviour and attitude towards information. In the broader perspective people's behaviours toward information relates to the concept of Information Behaviour and people's attitude toward information and information management practices refer to the Information Culture concept.

Information Culture and Information Behaviour are considered as important organisational features that have an impact on the effective use of information and records management (Marchand, Kettinger, \& Rollins, 2011; Wright, 2013). However, there appear to be no studies that investigate the impact of Information Culture and Information Behaviour on Information Quality.

At the same time, in Information Quality literature those factors that can be attributed to the concept of Information Culture and Information Behaviour are discussed without using the term "Information Culture" and "Information Behaviour". Those papers that aim to provide recommendations for overcoming information quality issues refer to the importance of people's information behaviour and of the information culture of an organisation in maintaining good quality information. Fox, Prybutok and Windsor (1999) recommend developing quality software and establishing focus on the quality of the information among employees. They believe that these actions should prevent bad Information from entering the Information System. English (2001) recommends transforming the culture of an organisation to make it information centric. That means that executive management should drive Information Quality initiatives and managers should be accountable for the information they create for other staff needs. Levis, Brady and Helfert (2008) argue that information quality management should be embedded in the culture and environment of an organisation. Thus, organisations should change and embed those elements of organisational culture that deal with information and people's attitude and behaviour towards information. English (2003) states that IQ problems should be solved by implementing the organisational 
management systems that influence employee behaviour. There are many indicators in Information Quality literature that Information Quality depends on different aspects of Information Culture and Information Behaviour. However, it appears that most authors did not identify the concept of Information Culture and Information Behaviour as such in their papers.

There are many disparate indicators in the academic literature observed that directly or indirectly point to the fact that people play a very important role in Information Quality and that how employees handle information and their attitude toward information, as well as Information Culture, have an impact on Information Quality. However, all these factors are scattered within the literature and in most papers all these information behaviour- and culture-related factors are considered in conjunction with other, IT, factors. Moreover, the fact that authors discuss the impact of Information Behaviour and Information Culture without referencing the concept of Information Culture and Information Behaviour strengthens the belief that "very little attention has been paid in Information Systems (IS) research to human information behaviour" (Johnston \& Tate, 2004). There is no proven well-structured model or study that explores the impact of Information Behaviours and Information Culture on Information Quality in either Information Culture or Information Quality academic literature. Although there are models indicating the impact of Information Quality on some aspects of organisational performance, it appears that there are no models which capture factors that influence Information Quality. So, there is a need to build a model and test it with the aim of gaining a detailed picture of how Information Culture of an organisation and Information Behaviours of employees influence Information Quality within organisations. 
Formulating research questions and objectives.

One of the main ideas that permeate almost all of the literature devoted to IQ is that IQ is of high importance for contemporary businesses.

There is strong evidence in the academic literature that Information Quality is important as it determines decision-making at all organisational levels, various organisational processes and outcomes, and implementation of different organisational programmes and technologies. Therefore it is important to know what factors may influence Information Quality with the aim of improving it. It has been shown that due to rapid development of Information Technologies the impact of people's information behaviour and values on Information Quality has increased. People in offices have fast access to a significant amount of information and they can now change or create the information within computer-based Information Systems. People's attitude towards information, people's actions toward information relates to the Information Behaviour concept and information values, information management practices within the organisation refer to the Information Culture concept.

The objective of this research is to study the impact of Information Culture and Information Behaviours on Information Quality in the organisational context. The research therefore addressed the following two questions:

RQ1. How do people's information behaviours influence Information Quality?

RQ2. How does information culture impact Information Quality?

Answers to these questions are intended to fill the gap in the literature that has been identified above.

In this research dispersed factors related to the Information Behaviour of people and to the Information Culture of an organisation will be organised in one theoretical model. The model will then be tested with the aim of identifying how different aspects of Information Behaviour and Information Culture influence Information Quality. 
Theoretical background of the research.

Information Quality.

The topic of Information Quality (IQ) is broadly discussed in academic literature. Researchers have explored Information Quality from different point of views revealing the problem from different angles and contributing to the body of research. The topic has been most widely investigated in the Management Information Systems (MIS) and Information Management (IM) research (Lee, Strong, Kahn, \& Wang, 2002).

Starting from 1980 the concept of an information as a product became broadly accepted since, historically, the principles of Total Quality Management (TQM) are applied to information quality (Shankaranarayan, Ziad, \& Richard, 2003). TQM philosophy "embracing all activities through which the needs and expectations of the customer and the objectives of the organisation are satisfied in an efficient and costeffective way" (Levis, Brady, \& Hulfert, 2008, p. 174). The most models presented in the literature are based on the "product" concept of the information.

English (2005) defines Information Quality as a consistent corresponding of the information needs and expectations of the knowledge workers and end-customers with the aim of fulfilling their business or personal objectives effectively. Following this definition, people who work in an office to assure the functioning of a company and its performance are knowledge workers. The end-customers are people who consume a company's products or services.

Lillrank (2003) believes that Information Quality remains a "vaguely defined concept" and has developed two distinct concepts for defining information and accordingly Information Quality. One of the concepts is "information-as-a-deliverable". According to this concept, information is produced to satisfy information needs, which are not fully and clearly articulated. This happens in situations where information needs and requirements change during the process of communication and information sharing. Such situations are common in tourism, when people, such as tourism managers and travellers, need to negotiate accommodation and flights. Information-asa-deliverable is of good quality when its commonly understood and "its meaning can be attributed to it with a degree of consensus and in the way that is perceived as useful". Lillrank's second concept considers information "as an artefact", the quality of which is predetermined and should be sufficiently described and defined. This situation is 
common in accounting where all reports have a standard format. In this case

("information-as-an-artefact") good Information Quality means that the information is "communicated in a way that the information receiver captures the intention of the sender" (Lillrank, 2003, p. 10).

In contemporary offices, there could be very complex working situations, when a team consisting of many people needs to create a single document or implement a project. In such circumstances, information requirements are not clear and are established during the collaboration and communication process. Information-as-adeliverable concept is most applicable for the office working situations. Combining the definitions of English and Lillrank and putting them into the office context, the next definition of information quality can be given: Information Quality is consistent correspondence to the information needs and expectations of office workers in such a way that provides information which is commonly understood and is perceived as useful for accomplishing business objectives. 


\section{Information Quality characteristics/metrics.}

As shown in Table 2 below, there are many Information Quality characteristics, attributes and/or measures, which vary from study to study depending on the context and assumptions of each Information Quality assessment model or methodology. Researchers have identified and classified Information Quality characteristics in different ways depending on their point of view. The same Information Quality characteristic/attributes have been classified into different categories by researches. For example, "believability" which is in the Intrinsic Information Quality Category in Wang and Strong's conceptual model, belongs to Subject Criteria in Naumann and Rolker's model.

\begin{tabular}{|c|c|c|}
\hline Researcher & Category & Characteristics/Criteria \\
\hline \multirow{4}{*}{$\begin{array}{l}\text { Wang and Strong, } \\
1996\end{array}$} & $\begin{array}{l}\text { Intrinsic Information } \\
\text { Quality }\end{array}$ & $\begin{array}{l}\text { Believability } \\
\text { Accuracy } \\
\text { Objectivity } \\
\text { Reputation }\end{array}$ \\
\hline & $\begin{array}{l}\text { Contextual Information } \\
\text { Quality }\end{array}$ & $\begin{array}{l}\text { Value-added } \\
\text { Relevancy } \\
\text { Timeliness } \\
\text { Completeness } \\
\text { Appropriate amount of } \\
\text { Information }\end{array}$ \\
\hline & $\begin{array}{l}\text { Representational } \\
\text { Information Quality }\end{array}$ & $\begin{array}{l}\text { Interpretability } \\
\text { Ease of understanding } \\
\text { Representational } \\
\text { consistency } \\
\text { Concise representation }\end{array}$ \\
\hline & $\begin{array}{c}\text { Accessibility } \\
\text { Information Quality }\end{array}$ & $\begin{array}{l}\text { Accessibility } \\
\text { Access security }\end{array}$ \\
\hline $\begin{array}{l}\text { Naumann and Rolker, } \\
2001\end{array}$ & Subject criteria & $\begin{array}{l}\text { Believability } \\
\text { Concise representation } \\
\text { Interpretability }\end{array}$ \\
\hline
\end{tabular}




\begin{tabular}{|c|c|c|}
\hline & & $\begin{array}{l}\text { Relevancy } \\
\text { Reputation } \\
\text { Understandability } \\
\text { Value-added }\end{array}$ \\
\hline & Object criteria & $\begin{array}{l}\text { Completeness } \\
\text { Customer support } \\
\text { Documentation } \\
\text { Objectivity } \\
\text { Price } \\
\text { Reliability } \\
\text { Security } \\
\text { Timeliness } \\
\text { Verifiability }\end{array}$ \\
\hline & Process criteria & $\begin{array}{l}\text { Accuracy } \\
\text { Amount of Information } \\
\text { Availability } \\
\text { Consistent representation } \\
\text { Latency } \\
\text { Response time }\end{array}$ \\
\hline \multirow{3}{*}{$\begin{array}{l}\text { Price and Shanks, } \\
2005\end{array}$} & Syntactic & $\begin{array}{l}\text { Conforming to } \\
\text { metaInformation }\end{array}$ \\
\hline & Semantic & $\begin{array}{l}\text { Complete } \\
\text { Unambiguous } \\
\text { Correct } \\
\text { Consistent } \\
\text { Meaningful }\end{array}$ \\
\hline & Pragmatic & $\begin{array}{l}\text { Accessible } \\
\text { Suitably presented } \\
\text { Flexibly presented } \\
\text { Timely } \\
\text { Understandable }\end{array}$ \\
\hline
\end{tabular}




\begin{tabular}{|l|l|l|}
\hline & & Secure \\
& Allowing access to \\
relevant metaInformation
\end{tabular}

Table 2. Summary of Information Quality characteristics/criteria.

At the same time, each framework or model contains some unique Information Quality characteristics. This leads to ambiguity and uncertainty in terms of choosing the Information Quality characteristics, which are the most valuable for a particular business context or for a research purpose.

Knight and Burn (2005) have analysed twelve Information Quality Frameworks and came up with the list of the twenty most common Information Quality characteristics. These are listed below, starting from the most common to the least common:
1. Accuracy
6. Concise
11. Relevancy
16. Navigation
2. Consistency
7. Reliability
12. Usability
17. Reputation
3. Security
8. Accessibility
13. Understandability
18. Useful
4. Timeliness
9. Availability
14. Amount of Inf-n
19. Efficiency
5. Completeness
10. Objectivity
15. Believability
20. Value-added 


\section{Wang and Strong's conceptual framework for Information Quality.}

Since information and Information possess the same quality characteristics, Data Quality and Information quality are used interchangeably. Wang \& Strong (1997) conducted an extensive study with the aim of identifying a set of Information Quality dimensions that are appropriate for users. Their study consists of two comprehensive surveys which allowed researchers to produce a list of twenty Information Quality attributes which were perceived as important by Information consumers. Then Wang and Strong (1997) applied a two-phase sorting study in an attempt to group Information Quality attributes into categories and thus develop a Information Quality framework appropriate for practical evaluating purposes. The final Conceptual Framework of Information Quality is shown in Picture 2 below. There are four Information Quality categories in the Wang and Strong Conceptual Framework. The Intrinsic Information Quality category includes the Information Quality attributes that are inherent in Information by itself. Contextual Information Quality reflects that the Information must comply with requirements in the context of the work performed.

Representation and Accessibility Information Quality refers to the role of the system in the security and representation of information.

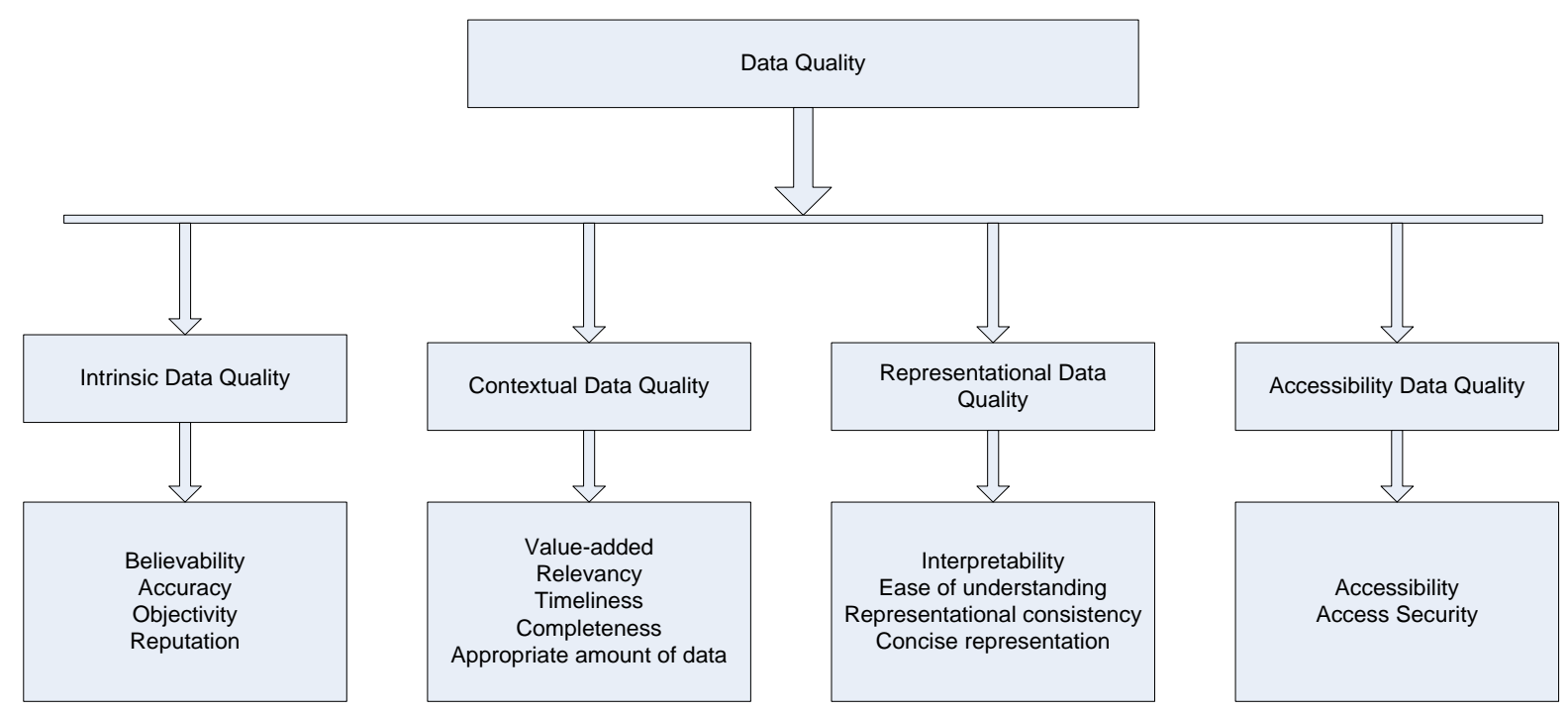

Picture 2. Wang and Strong (1997) Conceptual Framework of Information Quality.

The Wang and Strong (1997) model is focused on Information users' perceptions of which Information quality attributes are important, and how they should be grouped into categories. 
Later, based on Wang and Strong (1997) conceptual framework, the AIMQ methodology for measuring Information Quality was developed (Lee, Strong, Kahn \& Wang, 2002). In AIMQ model IQ dimensions are seen from the information consumer's point of view. IQ is measured as a quality of a product (Lee, Strong, Kahn \& Wang, 2002). The results of the IQ measurements are aimed at Information Systems professionals who are presumably responsible for Information Quality. However, in a contemporary office context, where each user of Information can also enter and edit Information, the boundaries between the responsibilities and the roles of Information Systems and Information professionals and users become blurred. 
Naumann and Rolker's (2000) approach to categorising Information Quality criteria is different to Wang and Strong's (2002) approach.
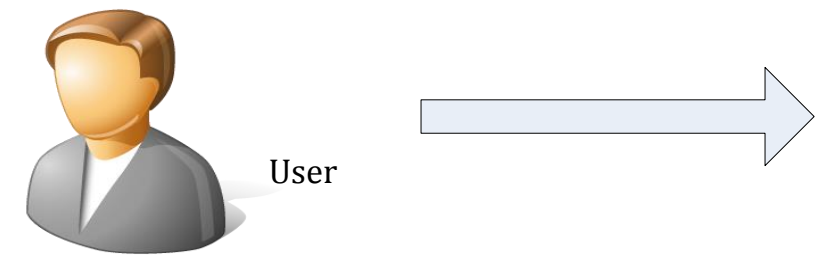

Subject-criteria scores
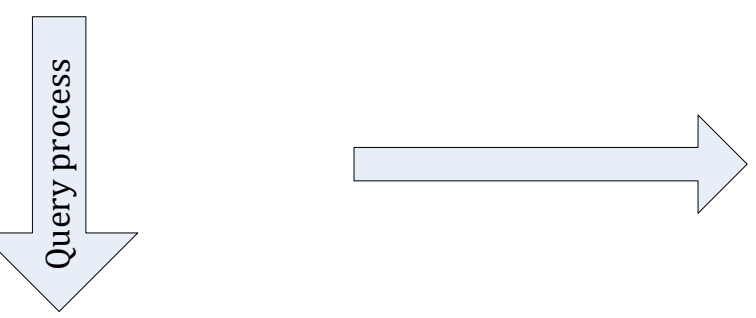

Process-criteria scores

Information source

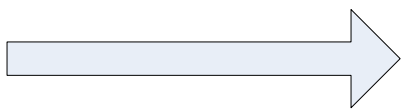

Object-criteria scores

Picture 3. Naumann and Rolker (2000) model. Sources of Information Quality criterions.

Naumann and Rolker (2000) developed a theoretical approach to assess the information source by assigning Information Quality criteria to three assessmentoriented Information Quality classes. The main point of their suggested classification and assessment approach is that Information Quality criteria/characteristics can be measured not only by relying on the subjective perception of users, but also by the objective assessment of the information itself and the retrieval process for accessing the information. According to Naumann \& Rolker, there are three main elements that influence and predetermine Information Quality: 1. the user; 2. the information; 3 . the retrieval system (Picture 3). Information Quality can be measured through studying users' perceptions of those Information Quality characteristics that appear to be subjective, such as understandability of the information. Those Information Quality characteristics that have been attributed to information are qualified as objective and could be measured by applying specific methods not involving people. Lastly, retrieval process related Information Quality characteristics are assigned in a separate Information Quality class/criterion. 


\section{Information Culture and Behaviour.}

There is no one single definition of Information Culture. The summarised Information Culture elements are shown in the Table 1. Choo et al. (2006) define Information Culture as an organisation's values, norms and practices towards the IM (information management) and use of information (as cited in Svärd, 2014). Their research underlines the crucial role of information culture in how people treat information. Svärd (2014) defines Information Culture as a set of human activities towards information, which includes value information and its quality, information and information sources management, and communication. Curry and Moore (2003 argue that Information Culture is part of organisational culture which refers to the information and which is conducive to effective information management. Information Management is considered to be effective if the value of information is recognised; if information is the basis for decision making; and if IT is exploited for effective information systems.

Davenport and Prusak (1997) use the term "Information ecology" instead of Information Culture to describe a holistic way of managing information. They describe information management as "a pattern of behaviours and attitudes that express an organisation's orientation toward information." Travica (2005) argues that Information Culture consists of two main components:

- information beliefs (assumptions, values, norms, attitudes) ;

- information behaviour (practices, rituals, communications).

\begin{tabular}{|c|l|l|}
\hline Author & $\begin{array}{c}\text { Practical activities } \\
\text { toward information (by } \\
\text { definition) }\end{array}$ & $\begin{array}{c}\text { Intangible elements of } \\
\text { Information Culture (by } \\
\text { definition) }\end{array}$ \\
\hline Choo et. al., 2006 & $\begin{array}{l}\text { Practices toward } \\
\text { Information management } \\
\text { and use of information }\end{array}$ & $\begin{array}{l}\text { Organisation's values and } \\
\text { norms }\end{array}$ \\
\hline Svärd, 2014 & $\begin{array}{l}\text { Information and } \\
\text { information sources } \\
\text { management; } \\
\text { communication. }\end{array}$ & $\begin{array}{l}\text { Value information and it } \\
\text { quality }\end{array}$ \\
\hline
\end{tabular}




\begin{tabular}{|c|l|l|}
\hline $\begin{array}{c}\text { Davenport and Prusak, } \\
1997\end{array}$ & $\begin{array}{l}\text { Information management; } \\
\text { Information behaviour }\end{array}$ & $\begin{array}{l}\text { Attitude to information; } \\
\text { information orientation } \\
\text { towards the information }\end{array}$ \\
\hline Travica, 2005 & $\begin{array}{l}\text { Information behaviour: } \\
\text { work practices, rituals, } \\
\text { communication. }\end{array}$ & $\begin{array}{l}\text { Information beliefs: } \\
\text { assumptions, values, } \\
\text { norms, attitude. }\end{array}$ \\
\hline
\end{tabular}

Table 1. Information culture elements.

Summarising different Information Culture definitions, it can be concluded that Information Culture consists of practical activities towards information and Information management (how people process and treat information) and intangible elements (how people value information and their attitude toward information). On the other hand, although according to Davenport and Prusak (1997) Information Culture underpins Information Behaviour, Information Behaviour can be separated into a distinct concept. Taylor defined information behaviour as people's activities through which "information becomes useful” (Taylor, 1991). Taylor gives the Information Behaviour definition on the individual level considering the type of person and the problem that needs to be solved. Davenport and Prusak (1997), defines Information Behaviour as "how individuals approach and handle information. This includes searching for it, using it, modifying it, sharing it, hoarding it, even ignoring it." Thus, Information Behaviour is observable people's actions towards and manipulation of information.

\section{Oliver's Information Culture model.}

Information culture can be defined as a subset of organisational culture that refers to Information Management and how people value and treat information (Oliver, 2008). Oliver (2008) developed a three levels model for assessing Information Culture:

- The first level of the model deals with the basic layer of an organisational culture. On this layer respect of the employees for information as evidence, respect for information as knowledge, willingness to share information, and trust in information are considered the main indicators of the information culture

- On the second level of the model employee skills, knowledge and experience related to information management are assessed. 
- The third, strategic, level is about information governance types and how they contribute to the Information Culture of an organisation (Oliver, 2013).

Curry and Moore's exploratory model.

In this model the user is considered as a contributor of information. Curry and Moore (2003) argue that both organisational and Information Culture have effect on information sharing and on the value of the information. Suggested components that are necessary for Information Culture are listed below:

- Communication flows. Having well established communication flows facilitates effective information sharing and well-informed decision-making. It is important that information flow easily in downward and upward direction as it ensures that managerial decisions are clearly communicated to everyone and that employees may provide feedback to management;

-Cross-organisational partnerships characterise how effectively different organisational functions and departments interact with each other;

-Internal Environment. For an open and co-operative information culture an atmosphere of trust is required;

-Information Systems management. Information Systems and Information Technologies provide mechanisms and tools for people's communication and cooperation. It is important how people adapt and adopt technologies implemented in the organisation;

-Information Management comprises different information management practices, including motivation and support people, information politics and policies. The main objective of Information Management is to provide access to the information that is necessary for execution daily tasks;

-Processes and Procedures. This element implies that information management guidelines \& documentation are of the right size and volume, and are concise and clear.

Kettinger and Marchand Information Orientation model.

The Kettinger and Marchand (2001) Information Orientation model gives good and detailed framework for assessing information values and Information Behaviours within a company. The Information Orientation of a company determines to what extent 
a company recognises information as a strategic resource and its capabilities to introduce and maintain proper information management practices, IT practices and information behaviours and values (Kettinger, Zhang, \& Marchand, 2000).

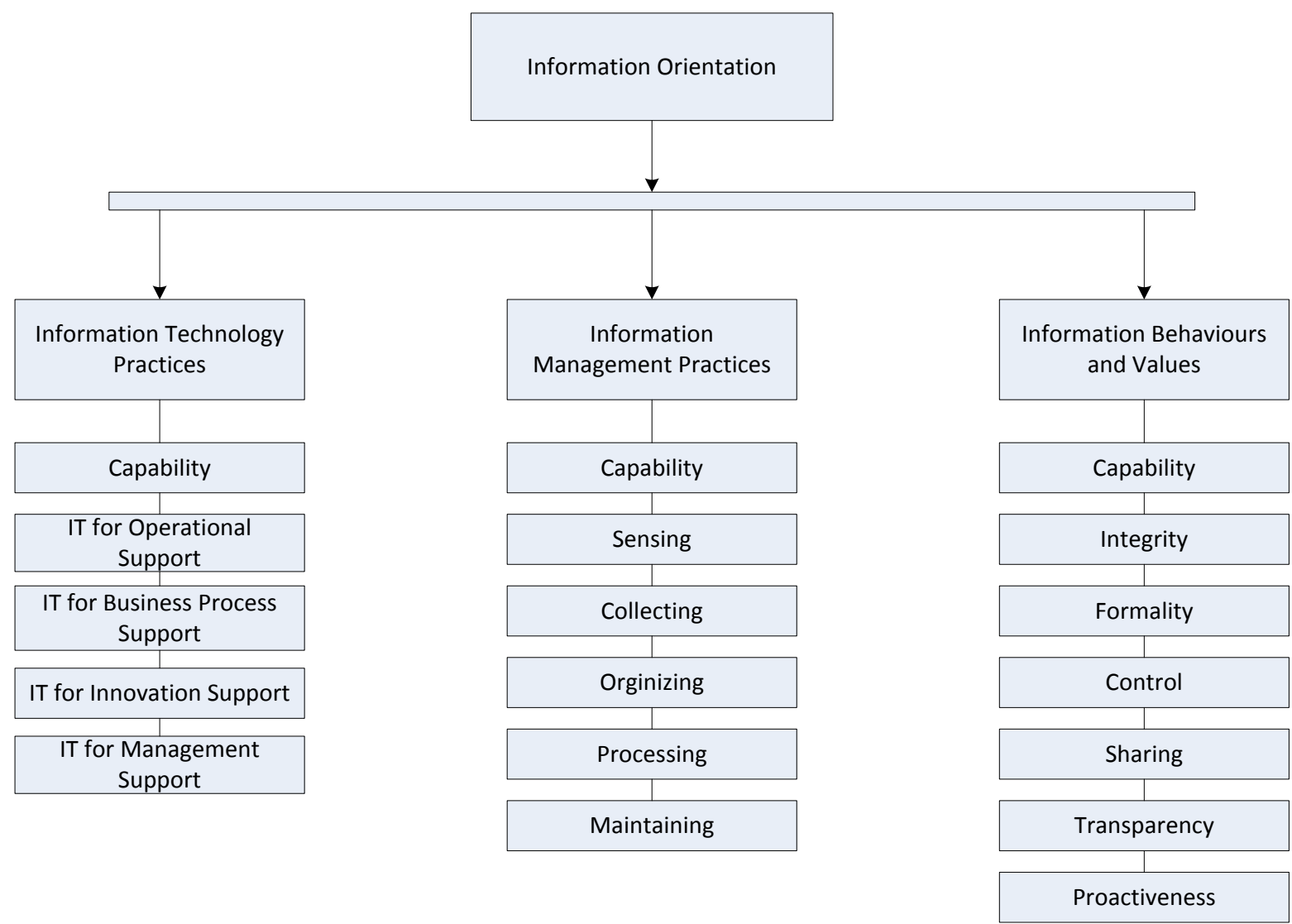

Picture 4. Kettinger and Marchand (2001) Information Orientation model.

Information Behaviour of employees is an essential element of the Information Orientation of a company and determines how effectively employees use information. This, in turn, influences overall performance of an organization. 
Developing research model and hypothesis.

From the literature review it can be concluded that modern organisations rely heavily and are dependent on information and Information Quality. Therefore, it is important to know which factors influence Information Quality so that it can be improved. However, although there are models indicating the impact of Information Quality on some aspects of organisational performance, it appears that there are no models which capture factors that influence Information Quality. So, there is a need to build a model and test it with the aim of gaining a detailed picture of how Information Culture of an organisation and Information Behaviours of employees influence Information Quality within organisations.

The impact of Information Culture and Information Behaviour is studied in this research. The constructs used in the research model are: Information Culture, Information Behaviour and Information Quality (picture, 5). These constructs were chosen as they are well established and accepted by other authors.

Many authors have pointed out that Information Management, Information Systems management and people's attitude toward information will drive Information Quality. In accordance with Fox, Guyness, Prybutok and Windsor (1997) Information Systems management influences the Information Quality. English (2008) states that IQ problems should be solved by changing the Information Management systems and principles that influence employees' behaviour. Developing and establishing a focus on the quality of information within the employees should have a positive effect on Information Quality (Fox, Guyness, Prybutok, \& Windsor, 1997). This implies that executive management should drive Information Quality initiatives and managers should be accountable for the information they create for other staff needs. Levis, Brady and Helfert (2008) suggest that Information Quality management that is embedded in the culture and environment of an organisation should have a positive impact on Information Quality. Thus, organisations should change and embed those elements of organisational culture that deal with information and people's attitude towards information with the aim of improving Information Quality. In other words, Information Culture that consists of practical activities towards information (Information management and IS management) 
and intangible elements (people's attitude toward information and Information Quality) should have positive effect on Information Quality.

H1: Information Culture dimensions have positive impact on Information Quality;

There are many causes of bad information relate to the Information Behaviour of employees. Repetitive handling of information by different individuals within a company, from Information collectors to top executives has a negative impact on Information Quality. According to the Data Warehousing Institute, one of the main sources of Information Quality problems is Information entry by employees (Trembly, 2002). It means that the way employees treat information influences Information Quality. Minton and Young (2009) argue that the major sources of Information Quality issues are deliberate lies and misinterpretation by suppliers of information. In addition, there are other reasons for Information Quality issues: translation, transformations and manipulations of information, information-entry and information acquisition errors. Bad information can be caused by using the same information for multiple purposes (Ballou, Kumar, \& Tayi, 1999). In this case information that is perfectly suited for accomplishing one person's working tasks might not work for another person with totally different objectives (Wand \& Wang, 1996). So, Information Quality depends on how openly employees report and present information, and how willingly they provide each other with information in an appropriate and trusted way. These can be combined into the Information Behaviour notion suggested by Marchand and Kettinger (2002). The next hypothesis will be tested:

H2: Information Behaviour has positive effect on Information Quality.

The items from previous research were used to measure and represent dimensions of the constructs. The dimensions used to explain each of the theoretical constructs in the research model (Picture 5) are taken from Kettinger, Marchand and Rollins (2001), Curry and Moore (2003) and the Lee, Strong, Kahn and Wang (2002) models. There are six dimensions of the Information Behaviour construct, which are used to describe how people treat Information from the practical point of view. The Information Culture construct consists of two dimensions that describe effectiveness of Information and IS 
management and people's attitude toward information and information quality. The IQ construct comprises 7 dimensions.

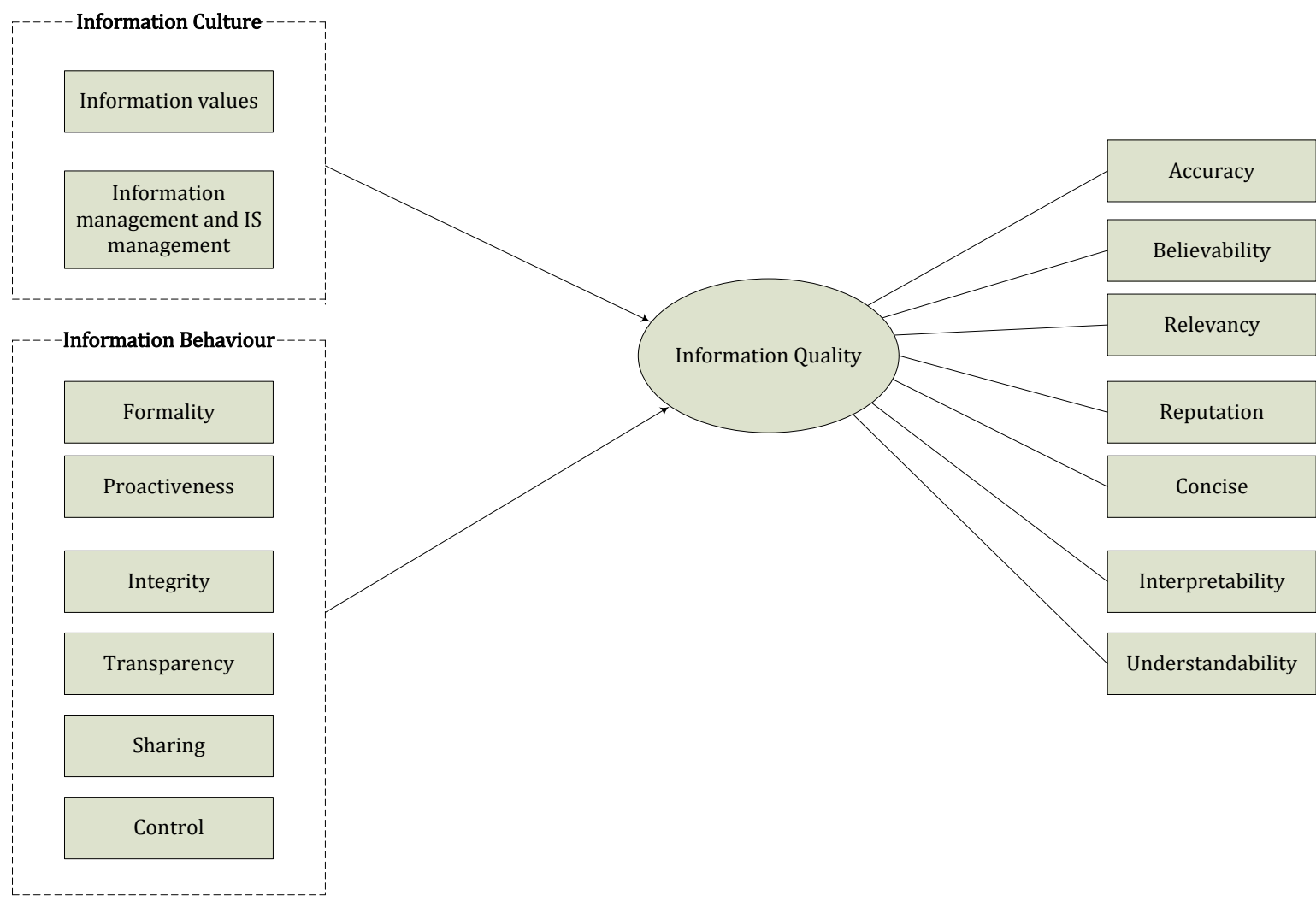

Picture 5. Research model.

The Information Culture construct is measured by two indicators: Information Values (10 items) and Information and IS Management (7 items).

The Information Behaviour construct comprises 6 dimensions: Formality (5 items), Proactiveness (3 items), Transparency ( 4 items), Integrity (5 items), Sharing (3 items), Control (5 items).

The Information Quality construct is measured by 7 dimensions: Accuracy (4 items), Believability (4 items), Relevancy (4 items), Reputation (5 items), Concise (6 items), Interpretability (5 items), Understandability (4 items).

Based on the Literature review, Information Culture embedded into an organisation is associated with a positive effect on Information Quality. Information Behaviours, such as open and free information sharing, have positive impact on Information Quality.

Table 2 shows the definitions of Information Quality characteristics, and dimensions of Information Culture and Information Behaviour which are measured in this research. 


\begin{tabular}{|c|c|c|}
\hline Construct & Dimension - definition & Reference \\
\hline \multirow[t]{7}{*}{$\begin{array}{l}\text { Information } \\
\text { Quality }\end{array}$} & $\begin{array}{l}\text { Believability - degree to which } \\
\text { information is accepted as correct; }\end{array}$ & \multirow{7}{*}{$\begin{array}{l}\text { Adapted from Lee, } \\
\text { Strong, Kahn, and } \\
\text { Wang (2002) }\end{array}$} \\
\hline & $\begin{array}{l}\text { Concise representation - degree to which } \\
\text { the structure of information matches the } \\
\text { actual information; }\end{array}$ & \\
\hline & $\begin{array}{l}\text { Interpretability - degree to which the } \\
\text { information conforms to technical ability of } \\
\text { the consumer; }\end{array}$ & \\
\hline & $\begin{array}{l}\text { Reputation - degree to which the } \\
\text { information or its source is in high standing; }\end{array}$ & \\
\hline & $\begin{array}{l}\text { Accuracy - extent to which information is } \\
\text { correct, reliable and certified free of error; }\end{array}$ & \\
\hline & $\begin{array}{l}\text { Relevancy - degree to which the } \\
\text { information satisfies the user needs; }\end{array}$ & \\
\hline & $\begin{array}{l}\text { Understandability - Degree to which the } \\
\text { information can be comprehended by the } \\
\text { user. }\end{array}$ & \\
\hline \multirow[t]{2}{*}{$\begin{array}{l}\text { Information } \\
\text { Culture }\end{array}$} & $\begin{array}{l}\text { Information values - how employees value } \\
\text { information and perceived importance of the } \\
\text { information as a strategic resource. }\end{array}$ & \multirow[t]{2}{*}{$\begin{array}{l}\text { Adapted from Carry } \\
\text { and Moore (2003) }\end{array}$} \\
\hline & $\begin{array}{l}\text { Information Management - motivation and } \\
\text { support people, information politics and } \\
\text { policies. The main objective of Information } \\
\text { Management is to provide access to the } \\
\text { information that necessary for execution daily } \\
\text { tasks; } \\
\text { Information Systems management - how } \\
\text { people adapt and adopt implemented in the } \\
\text { organisation technologies. }\end{array}$ & \\
\hline Information & Proactiveness is how actively people seek & Adapted \\
\hline
\end{tabular}




\begin{tabular}{|c|c|c|}
\hline \multirow[t]{6}{*}{ Behaviour } & $\begin{array}{l}\text { and use information which is useful for } \\
\text { enhancing products and services. }\end{array}$ & \multirow[t]{6}{*}{$\begin{array}{l}\text { Marchand, Kettinger } \\
\text { and Rollins (2001) }\end{array}$} \\
\hline & $\begin{array}{l}\text { Sharing - willingness to provide others } \\
\text { with information in an appropriate and } \\
\text { collaborative fashion. }\end{array}$ & \\
\hline & $\begin{array}{l}\text { Transparency - openness in reporting and } \\
\text { presentation of information on errors, } \\
\text { failures, and mistakes. }\end{array}$ & \\
\hline & $\begin{array}{l}\text { Control - extent to which information is } \\
\text { continuously presented to people to manage } \\
\text { and monitor their performance. }\end{array}$ & \\
\hline & $\begin{array}{l}\text { Formality - willingness to use and trust } \\
\text { formal information over informal sources. }\end{array}$ & \\
\hline & $\begin{array}{l}\text { Integrity - use of information in a trusted } \\
\text { and principled manner. }\end{array}$ & \\
\hline
\end{tabular}

Table 2. Definitions of Information Quality characteristics, and dimensions of Information Culture and Information Behaviour. 
Methodology.

The main object of the research is to study the impact of the Information Culture and Information Behaviours dimensions on Information Quality. Each dimension possesses different characteristics. Most of these characteristics can be studied only through the lens of human perception of it. Information Culture, Information Behaviour and Information Quality will be measured through the users' perception.

Developing measuring tools (questionnaire).

Different IQ questionnaires were analysed. It appears that all of them follow the principles and question design provided in Lee, et.al. (2002) model. The Lee, et. al. (2002) AIMQ model has been widely accepted and implemented for assessing Information Quality. Therefore, it is applicable for the purpose of this research. The Lee et. al. (2002) questionnaire has been used to assess Information Quality. The number of measured Information Quality characteristics was reduced to six selected on the basis of the Naumann and Rolker (2000) IQ assessment model. According to Naumann and Rolker (2000), there are three assessment classes of IQ characteristics: the Object class, the Process class, and the Subject class. In this research, only the IQ characteristics that fall into the Subject class are included in the model and are assessed and measured based on user experience and perceptions. Object class IQ characteristics and Process class IQ characteristics could not be measured within the framework of this project as I do not have access to the information sources of the participating organisations. Assessing all IQ characteristics goes beyond the timeframe of the research project.

The partially adopted approach developed by Kettinger, Marchand and Rollins (2001) has been used for assessing people's Information Behaviour. It was identified how willingly people share information, how transparently they report about issues and mistakes, and what sources of information - formal or informal - do people prefer..

A questionnaire adapted from Curry and Moore (2003) was used for assessing the Information Culture of an organisation. Only questions focused on information values and information management were included in the questionnaire. Through this I wanted to gain a better understanding of how well IM principles are established and embedded into an organisation. 
Statements were used to assess participants' perceptions of the Information Quality they used in the office on a regular basis, the Information Behaviour of employees and the overall Information Culture of the organization (Appendix A). Participants were asked to read the statements and then rank, on a five point Likert scale (strongly agree to strongly disagree), how they perceived Information Quality, Information Culture and Information Behaviour.

The online survey was selected as an empirical Information collecting method. A large number of responses might be collected in a reasonably short period of time. It gives an opportunity for further statistical analysis. The survey was built up using Qualtrics Online Survey Software.

\section{Data collection.}

An online survey was conducted with the aim of investigating the impact of Information Behaviour and Information Culture on Information Quality within the range of different organisations. The active phase of the responses collection lasted from 11 August till 10 September. The respondents of the questionnaire were Wellington based companies.

The organisations were identified by using the New Zealand Top 100 companies database retrieved from compass.co.nz and New Zealand Departments and Ministries list. Both information sources provide basic information about organisations.

The target companies for this research are enterprises of medium and large size because companies of this type, it may be assumed, have more information to work with.

According to the definition provided by the Ministry of Economic Development of New Zealand, small and medium sized enterprises (SME) consist of less than 20 employees. Medium enterprise is defined as those with 50-100 employees. Enterprises that employ more than 100 full time equivalent staff (ETS) are considered as big.

Then the final list of participating companies was created where companies included were chosen at random. It was decided to distribute the survey to as many office workers as possible with the aim of obtaining a wide variety of replies and therefore 
more comprehensive picture of the impact of Information culture and Information behaviour on Information quality.

The procedure of collecting Information was as follows. The CIO of the company from the sample companies list was sent an e-mail with Letter of Invitation for Participation in research and with the attached Information Sheet for participants (Appendix B). All documents were approved by the Human Ethical Committee (HEC) prior to sending.

If the CIO of a company accepted the Invitation for participation, he or she then disseminated the Information Sheet with the link to the online survey in it within the company.

Initially 23 CIOs were contacted. Since the results of this research had to be obtained within the fixed timeframe, the participants were asked to answer within a limited time period. Unfortunately this meant that some companies could not participate due to required formal procedures. Some CIOs rejected the invitation because for a variety of reasons.

75 people from 6 organisations took part in the survey. 14 people did not finish the questionnaire. 61 responses were collected. The responses of 51 people were completed for more than $80 \%$ and were accepted as valid for this research; 9 responses were completed for less than $20 \%$ of questions and were not used in the statistical analysis. 
Survey results analysis.

In the survey questionnaire, Likert items, measuring people's perception of Information Quality, Information Behaviour and Information Culture dimensions were used. There are two ways of processing participant's scores on Likert scale:

- one way is to sum up the values of each selected option and to create a score for each respondent;

- the second way is to count the mean of participants' scores for each option and to create a mean score for each respondent (Sreejesh, Mohapatra, \& Anusree, 2014).

In this research the second way has been chosen as preferable because different Likert scales have been used for different questions and further analysis might be complicated whereas averages will fall on the same 1-5 scale as the individual items for all questions.

\section{Factor analysis and reliability coefficient.}

The general purposes of the Factor Analysis are to reduce the number of items and to clarify the structure of the variables (dimensions) and to classify them. Factor Analysis by dimensions allow the researcher to identify the underlying dimensions of the research model and to test the dimensionality of the factors derived from the previous research.

In this research Factor analysis was run on IBM SPSS software. The principal component extraction method was used with Eigen values greater than 1 and Varimax rotation solution. The relationship of each variable to the underlying dimension is expressed by factor loading.

Cronbach alpha (reliability coefficient) is used to determine the consistency of the items in the group and shows how closely related a set of items is as a group. According to the rules of thumb interpreting alpha values (Hair, Money, Samouel, \& Babin, 2003, p.172) an alpha value of more than 0.6 was considered as acceptable for the purpose of this research. Cronbach alpha was calculated using IBM SPSS software. Although alpha value for Information values is less than 0.6 it was still accepted since the alpha score between 0.5 and 0.6 is deemed to be sufficient for the early stages of research (Nunnally, 1967).

Table3 summarises the factor loadings and Cronbach's alpha for Information Values and Information and IS Management dimensions. Factor analysis revealed that Information Values items load into more factors that it was supposed. 


\begin{tabular}{|c|c|c|c|c|}
\hline Construct & Dimensions (code) & Items & $\begin{array}{l}\text { Factor } \\
\text { loadings }\end{array}$ & $\begin{array}{l}\text { Cronbach's } \\
\text { alpha }\end{array}$ \\
\hline \multirow{17}{*}{$\begin{array}{l}\text { Information } \\
\text { Culture (IC) }\end{array}$} & \multirow[t]{10}{*}{ Information values (ICI); } & ICI1 & .815 & \multirow[t]{10}{*}{.581} \\
\hline & & ICI2 & .773 & \\
\hline & & ICI3 & .724 & \\
\hline & & ICI4 & .729 & \\
\hline & & ICI5 & .637 & \\
\hline & & ICI6 & .741 & \\
\hline & & ICI7 & .607 & \\
\hline & & ICI8 & .759 & \\
\hline & & ICI9 & .723 & \\
\hline & & ICI10 & .901 & \\
\hline & \multirow{7}{*}{$\begin{array}{l}\text { Information Management and } \\
\text { Information Systems } \\
\text { Management (ICIM); }\end{array}$} & ICIMS1 & .875 & \multirow[t]{7}{*}{.805} \\
\hline & & ICIMS2 & .670 & \\
\hline & & ICIMS3 & .721 & \\
\hline & & ICIMS4 & .626 & \\
\hline & & ICIMS5 & .826 & \\
\hline & & ICIMS6 & .609 & \\
\hline & & ICIMS7 & .541 & \\
\hline
\end{tabular}

Table3. Measurement of the Information Culture construct.

The factor analysis results for Information Behaviour items are shown in Table 4. Those items with factor loading less than .5 were considered as of low validity and removed from the model. The reverse coded items are marked with *.

\begin{tabular}{|c|c|c|c|c|}
\hline Construct & Dimensions (code) & Items & $\begin{array}{l}\text { Factor } \\
\text { loadings }\end{array}$ & $\begin{array}{l}\text { Cronbach's } \\
\text { alpha }\end{array}$ \\
\hline \multirow{7}{*}{$\begin{array}{l}\text { Information } \\
\text { Behaviour }\end{array}$} & \multirow[t]{5}{*}{ Formality (IBF); } & IBF1* & .755 & \multirow[t]{5}{*}{.621} \\
\hline & & IBF2* & .795 & \\
\hline & & IBF3 & .528 & \\
\hline & & IBF4* & .778 & \\
\hline & & IBF5 & .654 & \\
\hline & \multirow[t]{2}{*}{ Integrity (IBI); } & IBI1* & .847 & \multirow[t]{2}{*}{.802} \\
\hline & & $\begin{array}{l}\text { IBI2* } \\
\end{array}$ & .720 & \\
\hline
\end{tabular}




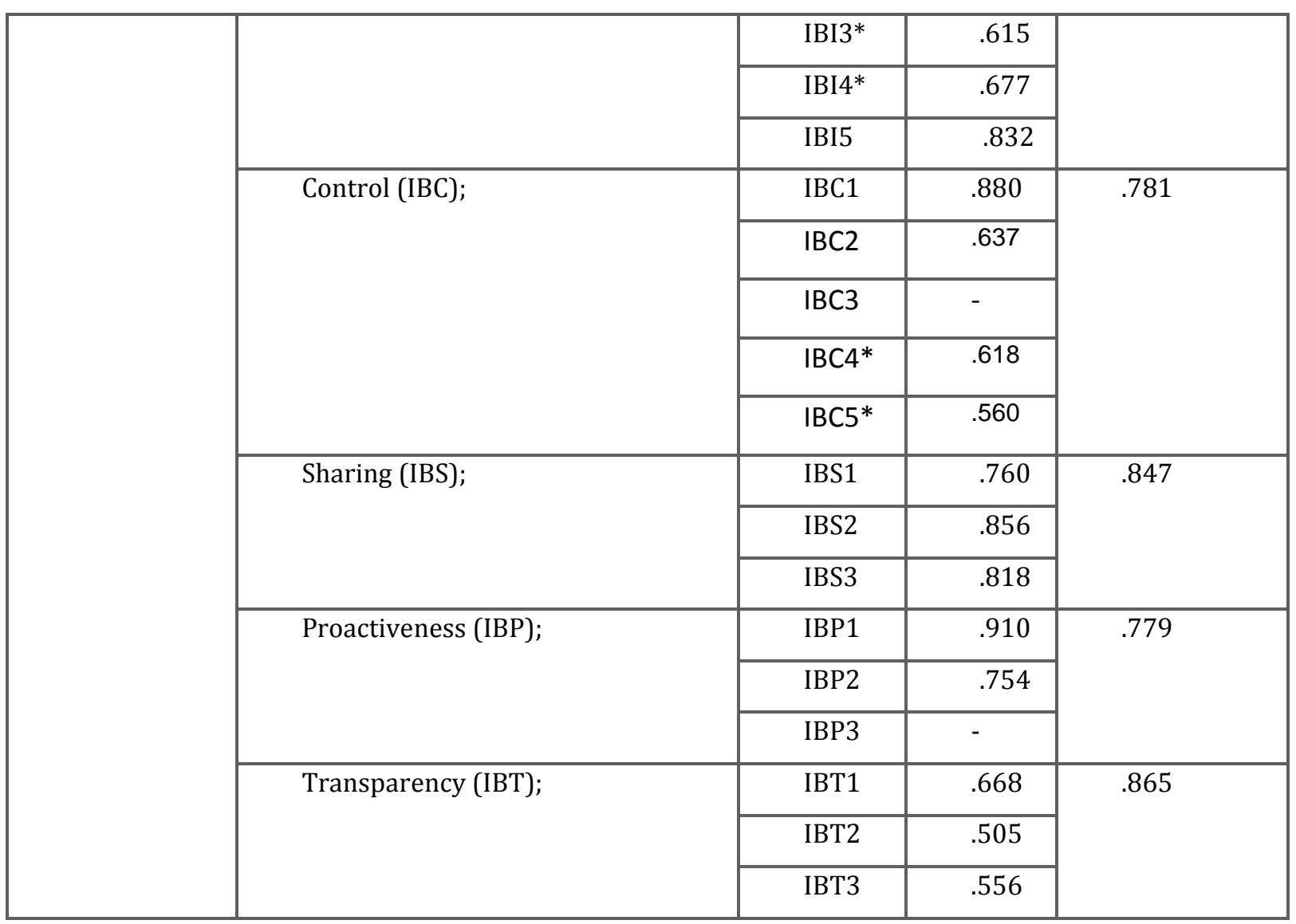

Table 4. Measurement of the Information Behaviour construct.

Table 5 represents the alpha values and factor loadings for the Information Quality items. The reverse coded items are marked with *.

\begin{tabular}{|c|c|c|c|c|}
\hline Construct & Dimensions (code) & Items & $\begin{array}{l}\text { Factor } \\
\text { loadings }\end{array}$ & $\begin{array}{l}\text { Cronbach's } \\
\text { alpha }\end{array}$ \\
\hline \multirow{9}{*}{$\begin{array}{l}\text { Information } \\
\text { Quality }\end{array}$} & \multirow[t]{4}{*}{ Accuracy (IQA); } & IQA1 & .511 & \multirow[t]{4}{*}{.906} \\
\hline & & IQA2 & .556 & \\
\hline & & IQA3 & .508 & \\
\hline & & IQA4* & .516 & \\
\hline & \multirow[t]{4}{*}{ Believability (IQB); } & IQB1 & .596 & \multirow[t]{4}{*}{.932} \\
\hline & & IQB2* & .700 & \\
\hline & & IQB3 & .747 & \\
\hline & & IQB4 & .689 & \\
\hline & Understandability (IQU); & IQU1* & .744 & .864 \\
\hline
\end{tabular}




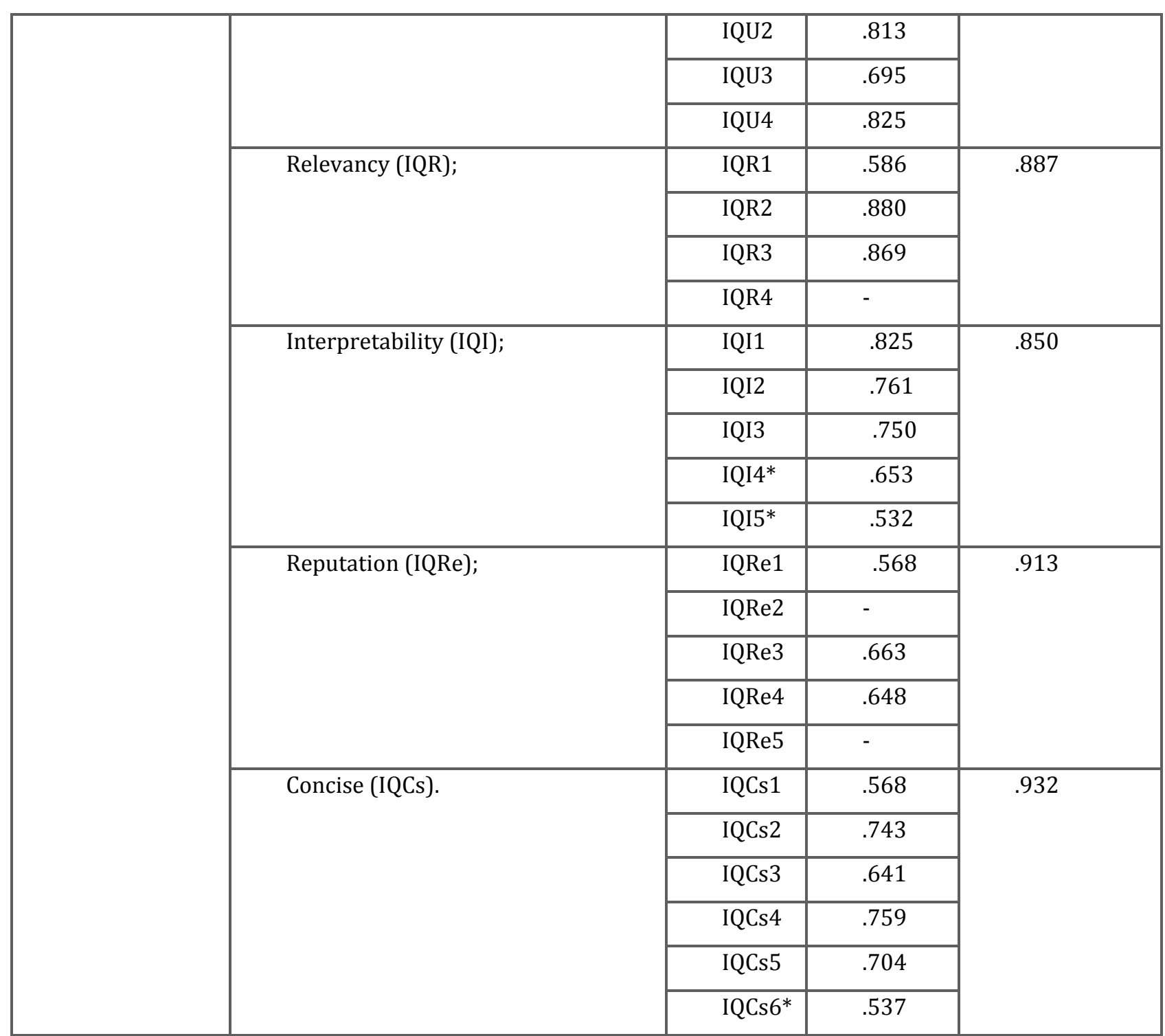

Table 5. Measurements of Information Quality construct.

\section{Regression analysis.}

In the research model, Information Culture and Information Behaviour are considered as the factors that influence Information Quality. However, these factors are multidimensional and consist of a number dimensions. Therefore, it was decided to run multiple regressions with the aim of finding out the importance of each dimension.

Multiple regression analysis was conducted to examine the relationship between Information Quality (dependant variable) and various predictors (Information Culture and Information Behaviour dimensions).

Table 6 summarises the multiple regression analysis output and provides details about the dimensions of the Information Culture construct and shows the predictive 
ability of individual independent variables (ICI, ICIM). The multiple correlation coefficient $(R)$ is a measure of the strength of the relationship between dependent variable IQ and independent variables (Sreejesh, Mohapatra, \& Anusree, 2014). In the case of Information Culture, $\mathrm{R}=0,7$ which tells us that there is moderate relationship between Information Culture dimensions and Information Quality. The value of $\mathrm{R}$ squared shows the amount of variation in Information Quality explained by two predictors IC and ICIM. Therefore, just $49 \%$ of the variation in IQ can be explained by the combined effects of the Information Culture dimensions. F value and Significance value says whether overall model is statistically significant (Sig. $<0,05$ ). If $p<0,05$ the result is statistically significant (Sreejesh, Mohapatra, \& Anusree, 2014). Our regression model results in reasonably good prediction of Information Quality $(\mathrm{p}<0.001)$.

Further statistics show which of the predictors (IC dimensions) has contributed significantly to the Information Quality variation. Standardised Beta values and significance (t-test) tells about statistical significance of each predictor variable (IC, ICIM). If $\mathrm{p}<0,05$ the corresponding predictor variable is significant in the model. It appears that both IC and ICIM have a reasonable statistical significance in determining Information Quality $(\mathrm{p}<0,05)$.

\begin{tabular}{|c|c|c|c|c|}
\hline Variable & $\mathrm{R}$ & R square & F-Ratio & Significance \\
\hline $\begin{array}{l}\text { Information } \\
\text { Culture }\end{array}$ & $.700^{\mathrm{a}}$ & .490 & 22.142 & $.000^{\mathrm{b}}$ \\
\hline & Dimensions & $\begin{array}{l}\text { Standardised } \\
\text { Beta }\end{array}$ & t-value & Significance \\
\hline & ICI & .278 & 2.173 & .035 \\
\hline & ICIM & .504 & 3.934 & .000 \\
\hline
\end{tabular}

Table 6. Multiple regression analysis. Information Culture construct.

As shown on the Table 7. Information Behaviour explains $82 \%$ of the variance in the Information Quality (R square=.822). The F-ratio of 32.246 with a significance of value $<0.001$ indicates that Information Behaviour has a strong relationship with the dependent variable.

IB dimensions except Transparency (IBT) and Sharing (IBS) determine information Quality significantly. 


\begin{tabular}{|c|c|c|c|c|}
\hline Variable & $\mathrm{R}$ & R square & F-Ratio & Significance \\
\hline $\begin{array}{l}\text { Information } \\
\text { Behaviour }\end{array}$ & $.906^{\mathrm{a}}$ & .822 & 32.246 & $.000^{\mathrm{b}}$ \\
\hline & Dimensions & $\begin{array}{l}\text { Standardised } \\
\text { Beta }\end{array}$ & t-value & Significance \\
\hline & IBI & .250 & 3.092 & .004 \\
\hline & IBP & .357 & 4.263 & .000 \\
\hline & IBT & -.111 & -1.196 & .239 \\
\hline & IBS & .149 & 1.818 & .076 \\
\hline & IBF & .447 & 6.355 & .000 \\
\hline & IBC & .235 & 2.747 & .009 \\
\hline
\end{tabular}

Table 7. Multiple regression analysis. Information Behaviour construct.

The hypothesis $1 \mathrm{H} 1$ : Information Culture dimensions have positive impact on Information Quality and hypothesis $2 \mathrm{H} 2$ : Information Behaviours has positive effect on Information Quality were supported by the study. 


\section{Discussion.}

This research project shows that the Information Culture of an organisation and the Information Behaviours of employees have a positive effect on Information Quality within the organisation. It means that organisations should facilitate Information Culture in their organisations and promote Information Behaviours such as integrity, proactiveness, formality and control among employees. These Information Behaviours should lead to better Information Quality. Thus, people should seek and use information in a trusted and principled manner, trust formal information and the information in formal information sources should be useful for their work and for enhancing the products and services of the organisation. An interesting result is that dimensions of Information Behaviours such as Integrity and Sharing do not have a significant impact on the Information Quality as was expected.

The research results have shown that Information Culture has a moderate positive effect whereas Information Behaviour has a reasonably strong effect on Information Quality. This may be the result of the limitations of the model. Not all Information Culture dimensions were included in the model and the interactions between Information Culture and Information Behaviour dimensions included in the model were not investigated in this research. Information Quality was measured through people's subjective perceptions. Object class IQ characteristics and Process class IQ characteristics were not measured within the framework of this project.

Although it was found that Information Culture has a positive effect on Information Quality, this effect is not as significant as was expected. Statistical analysis shows that Information Management and Information Systems management practices play more important role in maintaining Information Quality than Information Values of employees if not to say that Information Values do not have any reasonable effect on Information Quality. Research results support the opinion that Information Systems Management and Information Management practices that influence employees' behaviour have a positive effect on Information Quality (Fox, Guyness, Prybutok and Windsor, 1997; English, 2008). Indeed, if Information Management and Information Systems strategies are established within the organisation and are clearly communicated to employees, everyone in an organisation would be aware of how to manage information in a proper way. This, in turn, would lead to better Information 
Quality (such characteristics as accuracy and conciseness). Moreover, if Information Management and Information Systems Management adequately fulfil the information needs of employees so that employees have access to all information relevant to their work and this information is provided in a timely manner, it would have a positive effect on Information Quality (such as believability, relevancy and reliability of the information). Properly established Information Management practices among the employees might also affect Information Behaviour, Formality (the willingness to use formal information sources over informal), because if information provided in formal Information Systems relevant and timely to their work, people would then use such systems more willingly. Formality, in turn, has a positive effect on Information Quality.

Some authors have pointed out that Information Quality Management should be embedded into organisational culture and thus to shift organisational culture toward Information Culture. This would positively affect Information Quality (Levis, Brady \& Helfert, 2008). Also, developing Information Quality values among employees should positively affect Information Quality (Fox, Guyness, Prybutok, \& Windsor, 1997). However, the study presented has revealed that the Information Values of employees and their attitude toward Information Quality does not have any positive effect on Information Quality. This indicates that well-established Information Management and Information Systems Management practices and principles play a more important role for maintaining good Information Quality.

Another important factor that was explored in the research is Information Behaviour. It was shown that Information Behaviour has a reasonably strong positive effect on Information Quality. Therefore, the opinion that Information entry by employees has a strong impact on Information Quality (Trembly, 2002) was supported. This, in turn, will depend on how well Information Management practices are established in an organisation. According to Minton and Young (2009), deliberate lies and misinterpretations of information lead to poor Information Quality. In this research it relates to Integrity, the use of information in a trusted principle manner, which was found to be a factor with strong positive effect on Information Quality. However, Transparency (openness in reporting of information on errors and failures) does not influence Information Quality significantly. This phenomenon probably needs further investigation. 
It was expected that the use of the same information for different purposes would lead to poor Information Quality (Ballou, Kumar, \& Tayi, 1999). However, the research shows that Sharing (willingness to provide information to employees within the team and across functional boundaries) does not have any significant impact on Information Quality. Probably Interpretability and Understandability of the information depends on the format of the information rather than on its sharing. Therefore, the format of the information that is stored in Information Systems should be well prescribed in Information Management principles.

It appears that independent factors from the research construct are interrelated and might have an impact on one another. Interplays between the Information Culture, Information Management and Information Behaviour dimensions and certain combinations of them, might impact on Information Quality differently.

This paper might be useful for both theoretical researchers and practitioners in the field of Information management as it provides insight into how people's information behaviour and information culture influence information quality. Researchers might expand and test the provided model with the aim of gathering better knowledge of how to improve information quality within an organisation or of what other determinants of information quality exist. This study draws attention to Information Quality issues and explores how these issues might be resolved by implementing a certain elements of Information Culture and Information Behaviour. Information Management Practitioners might use the results of this study to improve or change Information Culture and Information Behaviour towards behaviours, which are more favourable for high Information Quality. This research draws an attention to the unexplored area and gives a tool and ideas for future research. Further research can investigate how different Information Culture and Information Behaviour dimensions influence different Information Quality characteristics. It might be useful for Information Management practitioners if they want to know how specific Information Behaviours influence Information Qualities which are most important for particular organisations. Also, different types of Information Culture and their effects on Information Quality might be investigated. The impact of Information Culture and Information Behaviour on Information Quality might be studied within organisations from different industries and 
of different size as well as on different organisational levels so that the more detailed picture can be obtained. 


\section{Conclusions.}

In spite of knowing the impact of poor quality information many companies still manage it in a very careless way. Many companies still overestimate their Information Quality. Maintaining good quality information is not an easy task since there are plenty of factors, from software quality to people's attitude toward information, that influence Information Quality in an organisation. Although much attention has been paid to technical factors that affect information, the influence of the human factor on Information Quality has increased recent years due to extensive use of information technologies.

This study has explored the impact of Information Culture of an organisation and Information Behaviour of employees on Information Quality thus the objectives of the study have been fulfilled. The results indicate that although Information Culture has a positive impact on Information Quality, this impact is not as significant as it was expected. Information values of employees and their attitudes towards information do not have significant influence on Information Quality whereas Information Management practices have strong positive effect on Information Quality. Information Behaviour of employees is positively related with Information Quality. However, some dimensions of the Information Behaviour, such as Transparency and Sharing, do not have impact on Information Quality.

The presented study can be useful for both Information Management practitioners and researchers. 


\section{References:}

1. Ballou, D. P., \& Tayi, K.G. (1999). Enhancing Data Quality in Data Warehouse Environments. Communications of the ACM. 42(1), 73-78.

2. Breur, T. (2009). Information quality is everyone's business - Managing information quality - Part 2. Journal of Direct, Information and Digital Marketing Practice, 11(2), 114-123.

3. Brouwer, H. J., Bindels, P.J.E., \& Van Weert, H.C. (2006). Information quality improvement in general practice. Family Practice, 23, 529-536.

4. Choo, C.W., Furness, C., Paquette, S., Berg, H., Detlor, B., Bergeron, P., \& Heaton, L. (2006). Working with Information: Information Management and Culture in a Professional Services Organization. Journal of Information Science, 32(6), 491510.

5. Curry, A., \& Moore, C. (2003). Assessing Information Cuilture - an exploratory model. International Journal of Information Management. 23, 91-110.

6. Clikeman, P. M. (1999). Improving Information Quality. The Internal Auditor. $56(3), 32$.

7. Conradie., P.J., \& Kruger., P. S. (2006). The necessity of Data Quality for effective Business Intelligence.South African Journal of Industrial Engineeri,. 17(1).

8. Davenport, T., H., \& Prusak, L. (1997). Information Ecology. Mastering the information and knowledge environment. New York, USA: Oxford University Press.

9. DeLone, W.H., \& Mc Lean, E.R. (2003). The DeLone and McLean Model of Information Systems Success: A Ten-Year Update. Journal of Management Information Systems, 19(4), 9-30.

10. English, L. P. (1996). Help for Information-quality problems. InformationWeek. $p$. 53

11. English, L. P. (2001). Information quality management: The next frontier. Annual Information Quality Congress Proceeding, pp.: 529-533.

12. English, L. P. (2008). The Information Quality Revolution. ASQ Six Sigma Forum Magazine, 8(1).

13. Fox., T. L., Guynes., C., Prybutok, V.R., \&Windsor, J. (1999). Maintaining quality in information systems. The Journal of Computer Information System, 40(1). 
14. Gonzales, P., Michael, L. (2004). The Information Quality Audit. Intelligent Enterprise, 7(11), 18.

15. Gorla, N., Somers, T. M., \& Wong, B. (2010). Organizational impact of system quality, information quality, and service quality. Journal of Strategic Information Systems, 19, 207-228.

16. Gustavson, M., \& Wanstrom, C. (2009). Assessing information quality in manufacturing planning and control processes. International Journal of Quality \& Reliability Management, 26 (4), 325-340. DOI 10.1108/02656710910950333.

17. Hair, J., Money, A. , Samouel, P., \& Babin, B. (2003). Essentials of business research methods. Hoboken, USA: Wiley.

18. Henderson, I., \& Murray, D. (2005). Prioritising and deploying Information quality improvement activity. Journal of Informationbase Marketing \& Customer Strategy Management,12 (2).

19. Howles, T.(2014). Data, Data Quality, and Ethical Use. Software Quality Professional. 16(2).

20. Jahangir., K., Somers, T. M., \& Gupta, Y. P. (2001). Impact of information technology management practices on customer service. Journal of Management Information Systems, 17( 4).

21. Johnstone, D., \& Tate, M. (2004). Bringing human information behaviour into information systems research: an application of systems modelling. Information Research, 9(4).

22. Kettinger., W., \& Marchand., D.A. (2011). Information management practices (IMP) from the senior manager's perspective: an investigation of the IMP construct and its measurementis. Info Systems, 21, 385-406. doi:10.1111/j.13652575.2011.00376.x

23. Khalil, O. E. M, \& Harcar, T. D. (1999). Relationship marketing and Information quality management. S.A.M. Advanced Management Journal; Spring 1999; 64, 2; pg. 26

24. Knight, S.-A., \& Burn, J. (2005). Developing a Framework for assessing Information Quality on the World Wide Web. Informing Science Journal, 8, 160171. 
25. Lee, Y. W., Strong, D. M., Kahn, B.K., \& Wang, R. Y. (2002). AIMQ: a Methodology for Information Quality Assessment. Information \& Management, 40, 133-146.

26. Levis, M., Brady, M., \& Helfert, M. (2008). Total Quality Management underpins Information Quality Management. The Journal of American Academy of Business, 14(1), 172-178.

27. Lillrank, P. (2003). The Quality of Information. The International Journal of Quality \& Reliability Management, 20 (6/7).

28. Mahanti., R. (2014). Critical Success Factors for Implementing Information Profiling: The First Step Toward Information Quality. Software Quality Professional, 16(2).

29. Marchand, D.A., Kettinger, W. J., \& Rollins, J.D. (2000). Information Orientation: People, Technology and the Bottom Line. Sloan Management Review, 41(4).

30. Marchand, D.A., Kettinger, W. J., \& Rollins, J.D. (2001). Information Orientation: The new business performance metrics. New York, USA: Oxford University Press.

31. Marsh, R. (2005). Drowning in dirty Information? It's time to sink or swim: A four-stage .Journal of Informationbase Marketing \& Customer Strategy Management, 12 (2).

32. Minton, G., \& Young, A. (2009). Information-Quality Matters. Mortgage Banking. 69(7), p.56.

33. Naumann, F. \& Rolker, C. (2000). Assessment methods for information quality criteria. Proceeding of $5^{\text {th }}$ International Conference on Information Quality, p.148-162.

34. Nunnally, J. C. (1967). Psychometric theory. New York, USA: McGraw-Hill.

35. Oliver., G. (2008). Information culture: exploration of differing values and attitudes to information in organisations. Journal of Documentation, 64(3), 363385. DOI 10.1108/00220410810867588

36. Pitney Bowes Business Insight. (2010). Information Quality: The foundation of Operational Effectiveness. White Paper: Information Quality. Retrieved from www.pbinsight.com

37. Price, R., \& Shanks, G.(2005). A semiotic information quality framework: development and comparative analysis. Journal of Information Technology, 20, 88-102. doi:10.1057/palgrave.jit.2000038 
38. Ramchandra, V., \& Sricant, S. (2006). Information Quality for Enterprise Risk Management. Business Intelligence Journal, 11(2).

39. Redman, T. C. (1998). The impact of Poor Information Quality on the Typical Enterpryse. Communication of the ACM, 41(2).

40. Setia, P., Venkatesh, V., \& Joglekar, S. (2013). Leveraging Digital Technologies: How Information Quality Leads to Localized Capabilities and Customer Service Performance. MIS Quarterly, 37(2), 565-590.

41. Shankaranarayan, G., Ziad, M., \& Richard, Y. (2003). Managing Information quality in dynamic decision environments: An information product approach. Journal of Informationbase Management, 14(4).

42. Sharabati, A.A., \& Hawajreh, K. M. (2012) The Impact of Organizational Information on Knowledge Management Practices. International Journal of Business and Social Science, 3(24).

43. Strong, D.M., Lee, Y. W., \& Wang, Y. (1997). Data Quality in context. Communications of the ACM, 40(5), 103-110.

44. Stvilia, B. (2007). A Framework for Information Quality Assessment. (2007). Journal of the American society for information science and technology, 58(12).

45. Svärd, P. (2014). The impact of information culture on information/records management: A case study of a municipality in Belgium. Records Management Journal, 24(1), 5-21. DOI 10.1108/RMJ-04-2013-0007.

46. Sreejesh, S., Mohapatra, S., \& Anusree, M. R. (2014). Business research: an applied orientation. New York, USA: Springer Cham Heidelberg. DOI 10.1007/978-3-31900539-3.

47. Taylor, R. (1991). Information use environments. Progress in Communication Science, 10, 217-251.

48. Travica., B.(2005). Information Politics and Information Culture: A Case Study. Informing Science Journal, vol. 8.

49. Trembly, A.C. (2002). Poor Data Quality: a $\$ 600$ Billion Issue. National Underwriter, p.48.

50. Wand, Y., \& Wang, Y. (1996). Anchoring Information Quality Dimensions in Ontological Foundations. Communications of the ACM, 39(11). 
51. Wang, R. Y., \& Strong, D.M. (1996). Beyond Accuracy: What Data Quality Means to Data Consumers. Journal of Management Information Systems, 12(4), 5-33.

52. Welzer, T., Brumen, B., Golob, I., Sanchez, J. L., \& Druzovec, M. (2005). Diagnostic Process From the Information Quality Point of View. Journal of Medical Systems, 29(1), DOI:10.1007/s10916-005-1104-0.

53. Wright., T. (2013). Information culture in a government organization. Examining records management training and self-perceived competencies in compliance with a records management program. Records Management Journal, 23(1), 1436. DOI 10.1108/09565691311325004.

54. Xu, H.Jeretta, H., Brown, N., \& Nord, G. D. (2002). Information quality issues in implementing an ERP. Industrial Management + Information Systems; 102, (1/2).

55. Yeo, E., \& Rudra, A. (2000). Issues in User perceptions of Information Quality and Satisfaction in Using a Information Warehouse - An Australian Experience. Proceeding of the 33rd Hawaii International Conference on System Sciences. 
Appendix A. Survey Questionnaire.

Questionnaire.

This survey is designed to assess your perceptions of the information quality that you use in your workplace for accomplishing daily tasks, and to assess the information culture and information behaviours within your organisation. It should not take any longer than 15 minutes.

I am particularly interested in answers that reflect your experiences and perceptions. However, all reporting will be on an anonymous basis and no organisation or individual will be able to be identified.

By participating you affirm that you are over 18 years of age and give your informed consent to participate. You are under no obligation to complete the survey and may discontinue at any time. However, incomplete answers may invalidate your responses. Thank you in advance!

The next two sections of statements deal with your perceptions of the INFORMATION CULTURE within your organisation.

The first section deals with Information.

Please, read each statement and click the relevant button to indicate the extent with which you agree with each statement.

Information should be the basis for informed decision-making at all levels of an organisation

Information is the basis for informed decision-making at all levels of our organisation

All decisions should be targeted at achieving the strategic aims and objectives of an organisation

All our organisation's decisions are targeted at achieving its strategic aims and objectives

Good quality information is critical to achieving our organisation's aims and objectives.

I have access to all the information I require to make decisions effectively

I am aware of the key information held by the organisation

I collate the required information on which to base my decisions myself 
I consult the Information Team (or similar) for information I require to make decisions effectively

I collate the information I require by accessing external information providers directly

This section contains statements relating to the Information Management and Information Systems applied in your organisation. Please, read the statements and click the appropriate button.

There is an Information Management and Technology (or similar) strategy for our organisation.

The organisation's IM and T (or similar) strategy adequately meets my information needs

The information systems in the organisation adequately meet my needs

I am confident using all the information systems to which I have access

The resources made available within or through the organisation adequately meet my needs

The organisation's key policies, processes and procedures for information systems are clearly documented

I know where to access the organisation's policies, processes and procedures

The next sections deal with your perception of different aspects of the INFORMATION BEHAVIOUR within your organisation. Please read the opening statements of each section and then indicate the extent of your agreement with each statement by clicking the appropriate button.

The first section deals with:

Formality - the willingness to trust and use institutionalized information.

Our people trust informal over formal sources of information

Our people trust informal sources of information

Formal sources of information are credible

Our people use informal sources to verify and/or improve the quality of formal sources

Our people trust the quality of formal information and do not need to rely on informal sources 
Proactiveness - the active concern to obtain information and the desire to put useful information into action

Our people actively seek out information on changes and trends

Our people use information to respond to changes in the environment

Our people use information to create or enhance products and/or services

Transparency - openness in reporting and presentation of errors, failures and mistakes

Our people trust one another to share information on failures

Management encourages openness

Information about failures, errors and mistakes is addressed constructively

Integrity - use of information in a trusted and principled manner

Frequently, our people knowingly pass on inaccurate information to their bosses or other employees

Our people frequently distribute information to justify decisions after the fact

Our people frequently keep information to themselves

Our people frequently exploit business information for personal gain

The strong personal integrity of our people enables effective sharing of sensitive information

Sharing - willingness to provide others with information in an appropriate collaborative fashion

Our people willingly share information within the team

Our people willingly share information across functional boundaries

Our people willingly share information with external stakeholders, e.g. customer, suppliers, partners

Control - extent to which information about performance is continuously presented to people to help manage and monitor performance

Information on business performance is presented to employees

Information on business performance influences working behaviour 
Our people use information to improve their performance

Information is so scattered that it is difficult to control people and/or processes

Information is distributed on a "need to know" basis so employees "know what to do" but "do not know why they are doing it"

The next two sections deal with your experience and your perceptions of the overall QUALITY OF INFORMATION you use in your workplace for accomplishing daily tasks.

The information is correct

The information is appropriate for our work

The information is sufficiently complete for my needs

The information is credible

It is easy to interpret what the information means

The information has a reputation for quality

The information is complete

The information is easily interpretable

The information covers the needs of my tasks

Any measurement units for the information are clear

The meaning of the information is difficult to understand

The information is useful to our work

The information is accurate

The information is reliable

The information includes all the necessary details

The information is difficult to interpret

The information in our information systems has a good reputation

The information is easy to comprehend

The information has sufficient breadth and depth for my tasks

The information is incorrect

The information is useful to our work

The information is of doubtful credibility

The meaning of the information is easy to understand

The information is has a good reputation

It is difficult to interpret any coded information 
The information is incomplete

The information comes from good sources

The quality of the information is high

The information is easy to understand

The information is believable

The information is trustworthy

The information is applicable to our work 
Appendix B. Information Sheet for participants.

Dear Fellow Business Person

My name is Anna Sinitsyna and I am a Master's in Information Management student in the School of Information Management at Victoria University of Wellington. As a member of the New Zealand workforce, I am inviting you to participate in my research, the details of which follow.

\section{Research Project Title: The impact of information culture and behaviours on information quality.}

As part of the completion of my Master's in Information Management, this study is designed to explore the extent to which an organization's information quality is influenced by people's information behaviours and the information culture of the organization. Specifically the research will aim to determine:

- The impact of information culture on information quality

- The impact of information behaviours on information quality.

Most of the decisions that are made in business are based on information, yet there has been scant attention to the measurement of information quality and the effect of factors that can influence it in an organization. This study explores the effect of two of those main factors: information behaviour in the organization and the information culture.

It will provide practitioners with insights into how information quality, itself, can be improved, plus how the effect of information behaviours and/or information culture within an organization can be enhanced so as to improve the information quality. All organizations would benefit from such insights.

Victoria University requires, and has granted, approval from the School's Human Ethics Committee. 
I am inviting business people who use information systems to accomplish their daily tasks to participate in an online survey which should not take longer than 15 minutes to complete. Participation is voluntary, and participants will not be identified in any written report, or possible academic conference paper or journal article produced as a result of this research. The final report will only deal with aggregated data but should your CIO or equivalent desire a special report for your organization that can be arranged beforehand but will only report on aggregated, anonymous data. Your organization has been selected because it is large and the benefits of the research will have a significant effect from the consequent economies of scale. All material collected will be kept confidential, and will be viewed only by myself and my supervisor, Assoc. Prof. Val Hooper. The research report will be submitted for marking to the School of Information Management, and subsequently deposited in the University Library. All data collected from participants will be destroyed within two years after the completion of the project.

If you have any questions or would like to receive further information about the project, please contact me at sinitsanna@myvuw.ac.nz or telephone 022-512-3450, or you may contact my supervisor, Assoc. Prof. Val Hooper, at val.hooper@vuw.ac.nz or telephone 463-5020.

If you agree to take part in the research, please follow this link http://vuw.qualtrics.com/SE/?SID=SV 1Cb3HFloMuq9CJv and complete the survey by 10 September.

Thank you, in advance. Your participation will be much appreciated.

Yours sincerely

Anna Sinitsyna 